C 8 

S 545

.08

Copy 1

\title{
BOYS' AGRICULTURAL CLUBS.
}

BY

\author{
DICK J. CROSBY, \\ Of the Office of Experiment Stations.
}

[Reprint from Yearbook of Departuext of Agriculture for 1904.] 


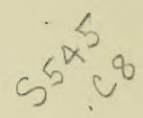

SEP 281907

$D$. ut D.

$\because \vdots \vdots$ 


\section{CONTENTS.}

The corn exhibit at the St. Louis Exposition $\ldots . . .1 \%$ Page.

Development of boys' clubs in Illinois .............................. 491

Boys' clubs in other States....................................... 493

School fairs ................................................... 494

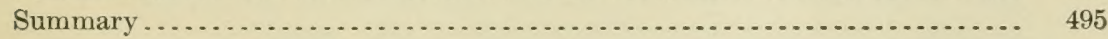





\section{ILLUSTRATIONS.}

Plate LXVIII. Boys' exhibit of corn at the St. Louis Exposition...........

LXIX. Boys' session of Winnebago County farmers' institute, Rock-

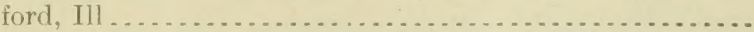

LXX. Fig. 1.-Winnebago County, Ill, boys in their field of sugar beets. Fig. 2.-Richland Township school fair in Keokuk

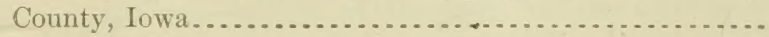





\title{
BOYS' AgRICULTURAL CLUBS.
}

\author{
By Dick J. Crosby, \\ Of the Office of Experiment Stations.
}

THE CORN EXHIBIT AT THE ST. LOUIS EXPOSITION.

"Grown by the farmer boys of Illinois!" "Eight thousand farmer boys in contest!"

All summer long these two legends surmounted two large pyramids of pure-bred corn at the Louisiana Purchase Exposition-pyramids made up of 1,000 little pyramids, each containing 10 beautiful ears of white or yellow corn, straight-rowed, symmetrical, uniform. The exhibit was a monument alike to the industry and intelligence of 8,000 Illinois farmer boys and to the energy and resourcefulness of Mr. Will B. Otwell, who had charge of the Illinois agricultural exhibit at St. Louis, and whose helpful work among these boys during the past four or five years made such an exhibit possible. A series of intensely interesting events leads up to this corn-growing contest, but only a brief sketch of them can be given here.

About five years ago the secretary of the Macoupin County (III.) Farmers' Institute, who had had some experience in advertising, undertook to get out a large attendance of farmers for the annual institute. He advertised the meeting in 13 county papers and instructed the janitor of the court-house to open the doors early to accommodate the crowd. On the day of the institute the attendance was limited strictly to the president, the secretary, and the chaplain. "And," says the secretary, "the chaplain offered a fervent prayer for the officers of the organization. I tapped him on the shoulder afterwards and told him he would oblige me by praying for the delinquent farmers who were absent; the officers were doing everything in their power."

The next year the secretary changed his tactics. After engaging the services of many noted speakers on subjects of interest to all good farmers, he had a lot of gilt-edged programmes printed. These were mailed, like wedding invitations, in nice square envelopes, to 500 farmers of the county. The day of the institute arrived, the janitor had the doors open early, and about two dozen farmers attended. The officers were disgusted, the president resigned, and the secretary was elected president. The latter, fortunately, was as resourceful as he was persistent, and his next experiment was both original and successful.

He first wrote to leading corn growers in Iowa, Indiana, and 
Illinois and procured 12 samples of first-class seed corn. He then called 12 farmers into the parlors of a local bank and asked them to select the variety best adapted to the soil of Macoupin County. This done, several bushels of the seed corn were secured at $\$ 2$ per bushel. The president next solicited $\$ 40$ in cash and divided it into $\$ 1$ premiums. A plow company gave a two-horse plow to be offered as a sweepstake premium. Notices were then inserted in the county papers to the effect that every boy under 18 who would send in his name and address would receive a package of this seed corn-all that could be mailed for 1 cent postage. The president says:

Five hundred-boys sent for the corn and began contesting for,the premiums. All summer long these boys were talking farmers' institutes (where the corn was to be exhibited). They were comparing notes and exchanging ideas until our institute was a topic of general conversation. I decided not to advertise the institute in the papers any more than just to give the dates. The farmers were politely told they could stay away from the institute if they preferred. When I reached the courthouse on the morning of the institute there were scores of boys waiting for the doors to be opened. They had their prize corn with them, some of it in boxes, some of it in coffee sacks, tied up with binder twine, shoe strings, bedcord-any way, just so they got it to the institute. When $I$ called that meeting to order at the appointed time I was confronted by 500 farmers. And Professor Stevenson, of Champaign, who scored the corn, said he had never seen a nicer display of yellow corn. I knew I had solved the problem, and so did the farmers. The boys were in evidence everywhere, and their presence was an inspiration to the institute.

The next year there were 1,500 farmer boys in the contest, and it took $\$ 300$ to provide the prizes, which consisted of a high-grade bicycle, a three-wheel riding plow, a walking cultivator, a 10 -foot windmill, a fanning mill, a double harrow, a 16 -inch walking plow, a washing machine, a one-hole corn sheller, a hand plow, 2 rolling colters, a box of 100 bars of soap, and 140 one-dollar premiums.

The summer that followed was a dry one, and the president of the institute was fearful that the contest would not amount to much. But one of the objects for which he was striving had already been accomplished-the farmers of the county were interested. The fathers of the 1,500 boys donated the best spots on their farms for the growing of this corn-the hog lots, calf pastures, clover fields - and all the time the boys were studying deep and shallow cultivation and fertilizers of all kinds, and were becoming more interested in farming, "so that to-day there is a prevailing belief in this county that boys may choose farming as a profession and still be as good as anybody."

When the time for the farmers' institute came there were 1,500 farmers in constant attendance and a display of corn which, according to the judge who distributed the prizes, was finer tban any he had ever seen at State fairs in Illinois, Indiana, Kansas, or Iowa. Mr. Otwell says of this meeting:

Farmers who two years before would not attend, and who boldly asserted that "they had forgotten more than those speakers would ever find out," were on the 
front seat and helping in every possible way. Besides the fathers and mothers and sisters and sweethearts, there were more than 300 farmer boys in attendance at this institute, and with no friction and the utmost enthusiasm and good will, we closed the largest and best farmers' institute I have ever attended. The corn was simply immense. And so were the boys. And when I mentioned the name of the poor little fellow in blue overalls, who lived on a thin, worn-out piece of white land, and who had carried water all through the long summer to water his corn, and had thereby been awarded the first prize (bicycle), no governor of the State of Illinois ever received a heartier ovation than he.

The problem of arousing an interest in farmers' institutes and in the questions discussed at them haul heen solvol. The farmers were reached through their children, and the interest thus aroused will be handed down to their children's children.

When the president of the Maroupin County Falmers' Institute was asked to take charge of the Illimeis agricultural exhibrit at the Lonisiana Purehase Exposition he derermined that the farmer hoys should take an active part in preparing the display. He get up at list of premimms (osting sis, son, printed the premimm list and the rules gorerning the contest, and mailed them to 120,000 farmer boys in Illinois. Eight thousand of these boy sent for the -imple pretiagere of com and went to work.

The exhilit, an it was finally prepared and in-talled in the Palace of Agriculture (PI. LXVIII), consisted of over 1,000 entries of ten ears each. The corn was of excellent quality and quite uniform in appearance and measurement. The prizes ranged from sol cente to siser), and 1,250 exhibits received atrards.

Eight thousand boys in a single State thoroughly aroused on the sul,ject of improving corn! Think what purer has heen set in motion?

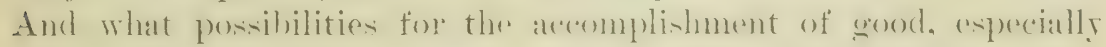
when the interest thus aroused is extended to other matter's, to the improvement of rural conditions generally!

\section{DEVELOPMENT OF BOY' CLUBS IN ILLIYOIS.}

And yet, the series of corn-growing contests just described is but one of a number in Illinois. all developed more or lese directly under the auspices of the State College of Agriculture, the Illinois Farmers' Institute, and the county institute secretaries and county superintendents of schools. Seed hat heren furnished by the college and the farmers" institute. and contests bare heen arranered by the local author-

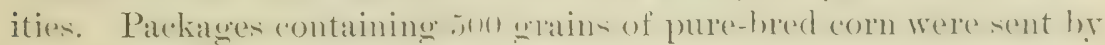
the state Farmers' Institute to over s.tum boys in 19!1t. The need of local ansociations through which the county superintendents and secretaries could work more effeetually hat led to the organization of clubs among the hoys, usually hy township. with a county asurediation of clubs. Probably a dozen different counties have started the club 
morement, and sereral of these have strong and rery active organiza. tions. In Winnebago County the (duh membership) was 425 in 1904 , and in .Johnson County it was 535. The State superintendent of farmers' institutes estimates that the total membership for the State is not less than 2,000 .

The work of the boys clubs is not confined to growing pure-bred corn, but also includes the testing of varieties of sugar beets, institute work, the judging of corn, visits to leading farms, and excursions to the State College of Agriculture. In thirty counties of Illinois last year one sesion of the farmers institute was given over to the hoys. In Winnehago Comnty the Boys Experiment (Hub has a regular place on the county insitute programme (PI. LXIX). Its memhers also meet at some of the best farms in the comity to study the different crops, examine the buildings and live stock, and see the improved machinery in operation. Their experiments are something more than the growing of a small plat of corn. sugar beets (Pl. LXX. fig. 1), or soy beans: they include also the study of farm management, fertility, prevalence of harren stalki and smut -all of the conditions likely to affect materially the rield and quality of the crops grown. Note the points hought out hy one of the boys in the corn-growing experiments in the following report to County superintendent of Schools O. J. Kern. who has developed this work in IV immelago County:

REPORT OF HARRY M'FARLAND.

My experimental corn was the Leaming corn. I planted my prize-growing corn on the 7 th of May in a plat that contained 3 square rods. The soil was a black, sandy loam. The ground had garden truck on it last year, which left it in good condition for corn this year. The ground was plowed with a 16 -inch plow at a depth of 6 inches. I planted my corn in rows 3 feet wide, the hills being 2 feet apart. The corn was up within 3 days and averaged 2 stalks to the hill. My corn had a good many suckers on, but very little smut. The corn averaged 12 feet tall, many stalks haring 2 ears on. The work I put on my corn is as follows:

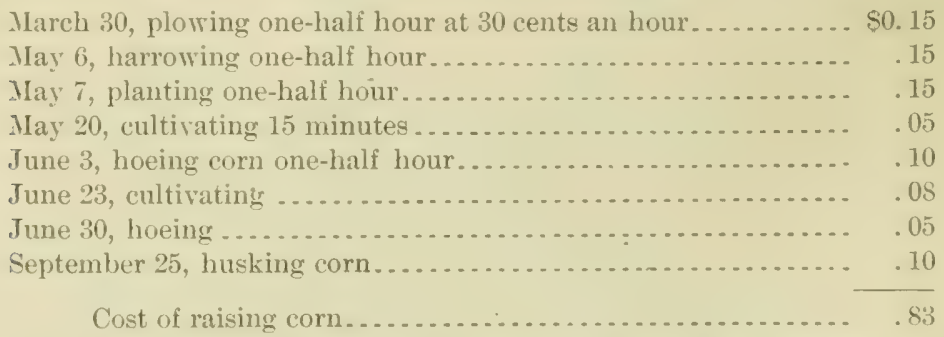

The total yield of corn was $2 \frac{1}{2}$ bushels. The value of the corn was $\$ 3$. The gain. Tas $\$ 2.17$.

These Wimnebago hoys also have their lecture contses where, ambong other things, they leam ahout corn judging. from Profersor IIolden,

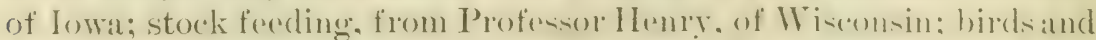
their benefit to the farmer, from I'rofenor I exirborne of the Field 


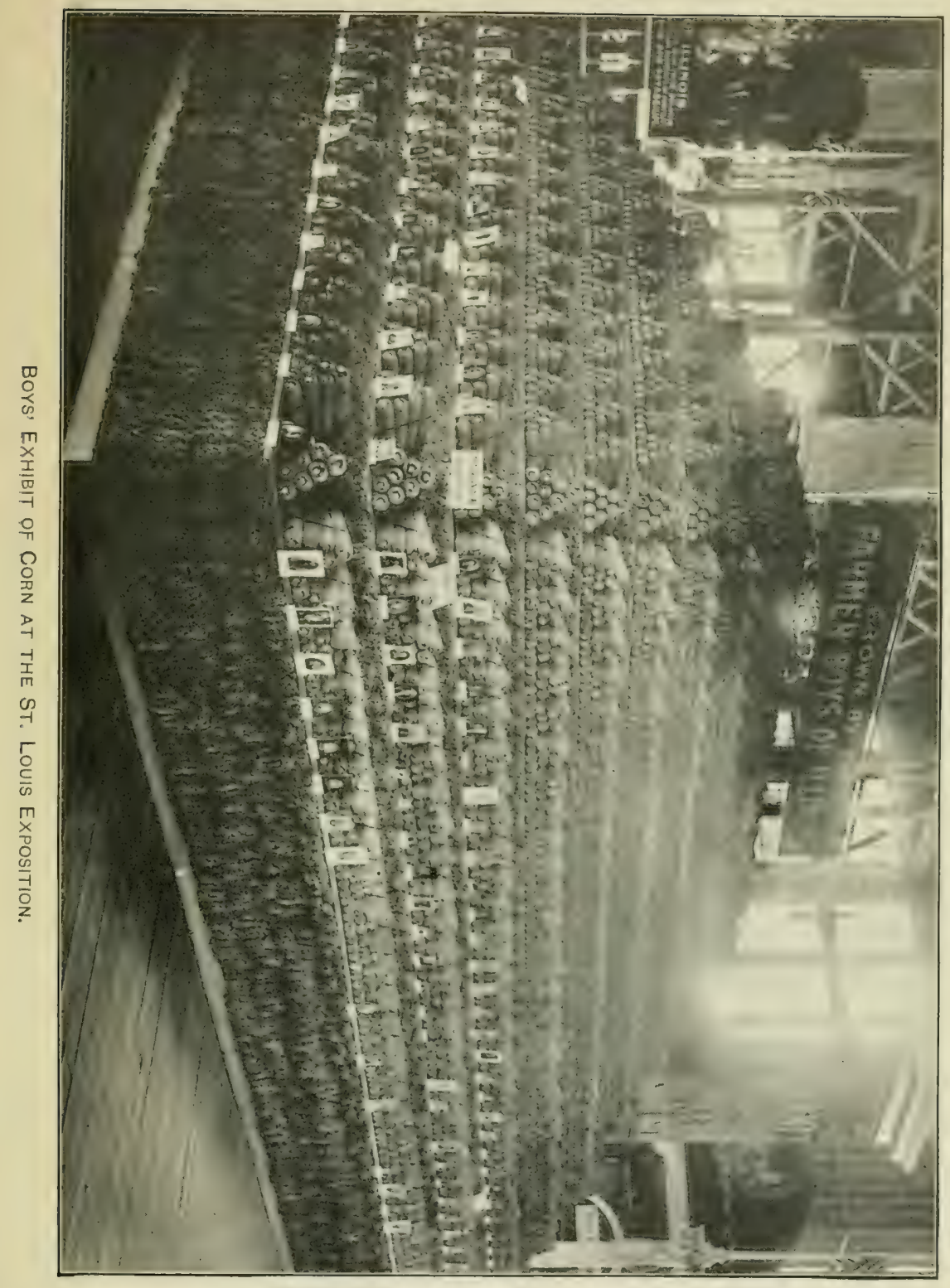





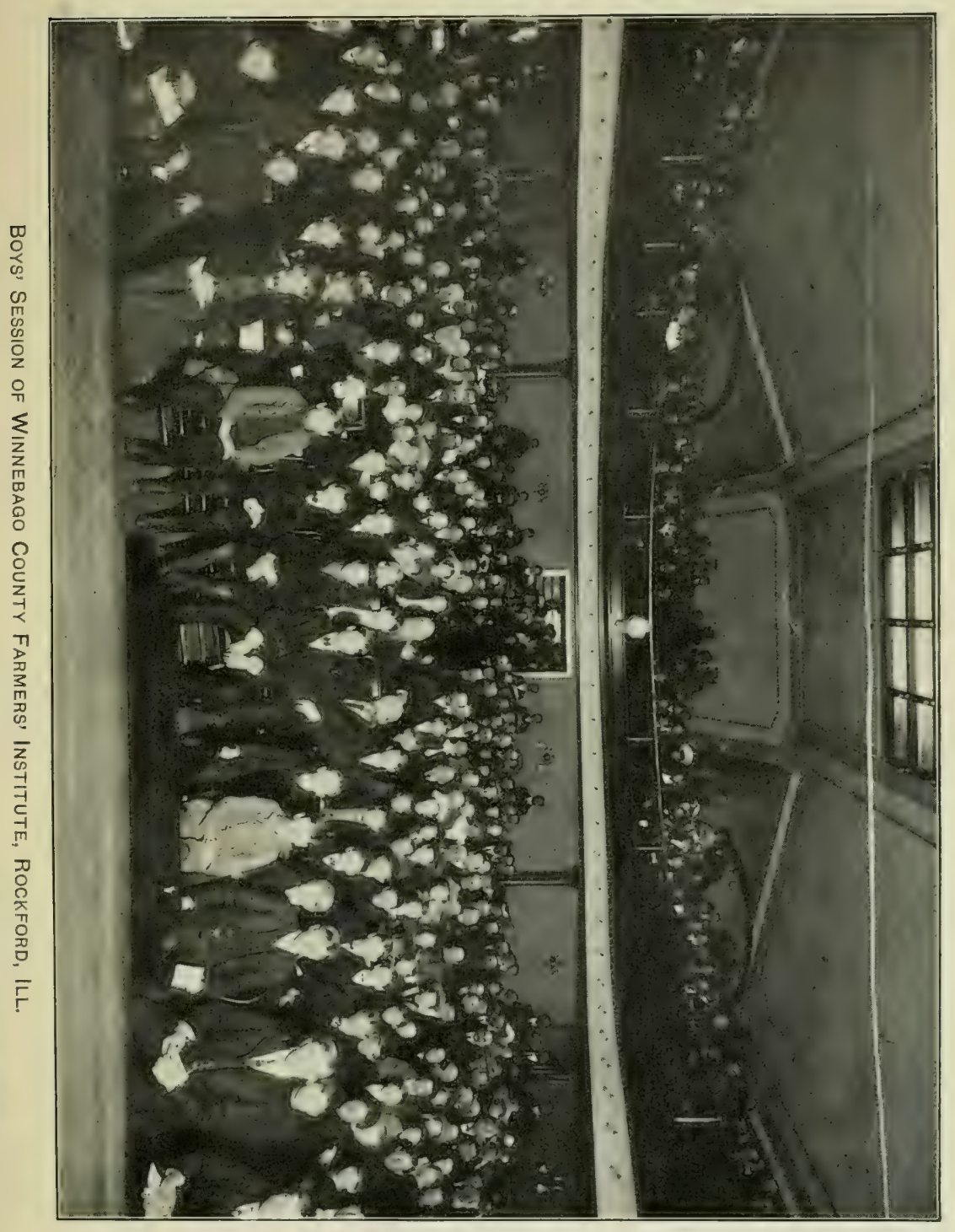



Columbian Museum; and the kind of country schools for country people, from Professor I avenport, of Illinois. They have acerese to excellent traveling school libraries, containing a liberal -p prinkling of standard agricultural books, and the bulletins and other publications of the State experiment station and of the ['nited States I)repartenent of Agriculture, and at commencement time receive diplemas or other restificates for the rearling done during the year. They have been on several long excursions, including two to the Illinois College of Agriculture at Urbana, and one to the Iowa Agricultural College at Imes. This gear they gon to the Wirensin College of Agriculture at Mardisom. At these agricultural institution- great pains is taken to -how the bogs the magnificent erquipment in buildings, appoaratus, and live storek and to take them oser the field experiment.s. Thery erome home talking

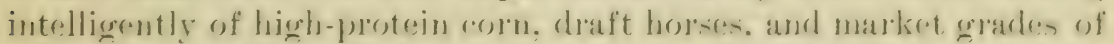
besef cattle. Cirarlually but -urely it grows upon them that it is not all of forming to drudge: that there is abundant opperstunity to plan. sturly. incertigate: that intelligenee and culture are neerded on the

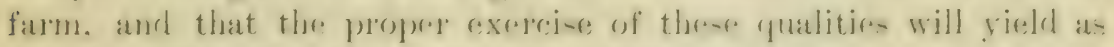
abundant returns in the country as in the city.

\section{BOYS' CLLBS IN OTHER STATES.}

Illinois is not alone in this forward movement. Iowa, Ohio, and

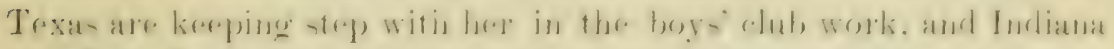
and New York have taken up the boys' institute work-the former with 1.5 mereting- late year and the latter with iz. Indered, if may he said that New York, with its 20,000 or more members of "Junior

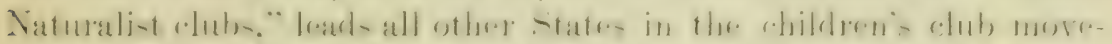

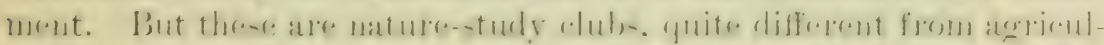
tural clubs, and they are for girls as well as boys. There are also girls' clubs in these other States-Illinois, Iowa, Ohio, and 'Texas-

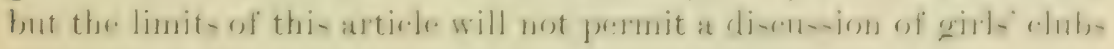
or nature-study clubs.

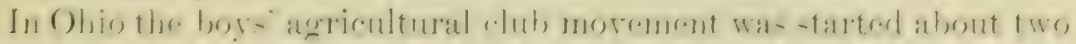

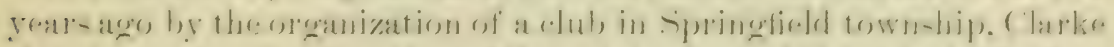

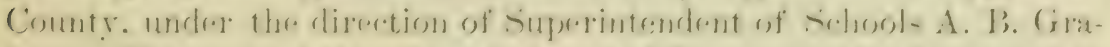

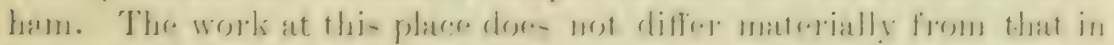

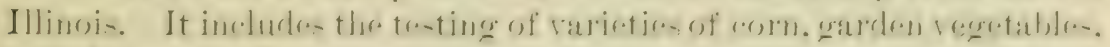
and flowers, and some work with insects, wild flowers, weeds, and soils. 'There are now 16 boys' agricultural clubs in 10 counties of

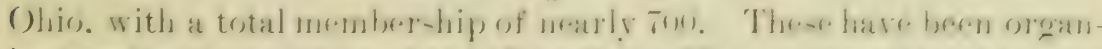

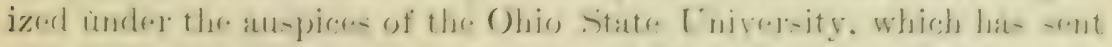

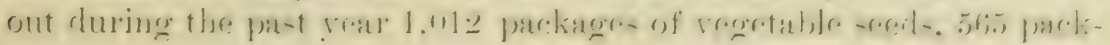
agges of corn, and 1,261 packages of fiower seeds, besides a large ancount of litmus paper for uns in tw-ting the areidity of ersile. 
The Texas club morement was organized only a little over a rear ago in connertion with the Texas Farmers' ('ongress, but the membership of the Farmer loys and (Birls Letgue is now over 1,201. In Iowat the first rlub wate organized by County superintendent of Schools (atp E. Miller', at Figomener, Keokuk ('ounty, in Mareh, 19m4. This .huh now has a memhership of :39.5 boys. and its first rear hats been one of mentiable aretivity and progress. It has held several meetings. hat made sereral excursions. inclubling one to Ames and another to one of the litrese ranches in the state, and it has eonducted a series of school fiars that are worthy of brief description.

\section{SCHOOL FAIRS.}

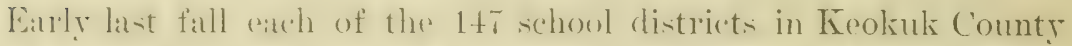
helle a shoul fair. where the hors exhibited all worts of fruits. regetables, and farm crops which they had grown. The best and second best articles of each class were later entered at township fairs-one in each of the 16 tornships in the county (Pl. LXX, fig. 2). In connection with each fair a programme was rendered consisting of talks and papers on corn, potatoes; peannts, apples, and other fruits and crops, together with recitations and musical selections. All of the

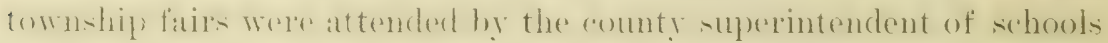
and the president and the secretary of the boys' alub of the county,

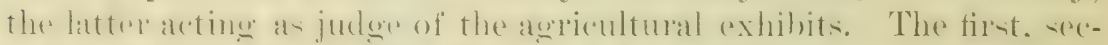
sond. and third prize articles from carch township far were then exhibited at at couty achuol fair. This was held in the high school building at Sigourney, December 2t, and was attended by over 1,000 people. The exhibit contained more than $3.0 m$ anticles and wat probably the

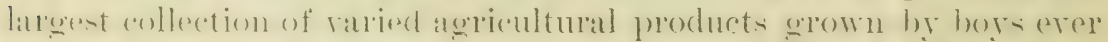
hronght togenther in this contry. Profenorer Holden and Mr. ('hristie.

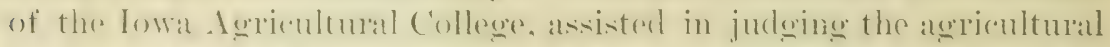

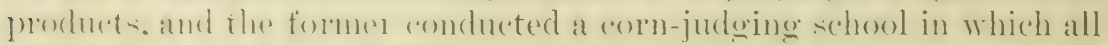
of the hoys teok patt. The programme rendered in connection with the fair induted mu-ice leseitations, a dehate on the subject " Resolved. That (onm is more l werful than ('otton," and at composition contrest in which rateh grated school in the county was allowed one representative. The gemeral theme of the comporitions was " An Interesting Ilant." eatch contextant presinting a paper on some particular plant. Theres were 10 compositions on corn, 3 on wheat, 3 on the tomato, and 1 or 2 on each of a dozen other common farm crops or flower's. Superintentent (al) E. Miller. who wat the organizer and moring spirit in all this work, says of the fair:

It was the greatest educational meeting ever held in the county. The interest which it created has spread in its inflnence to all the work of our rural schools and has caused the farmers of our county to organize a farmers' institute. *** * 


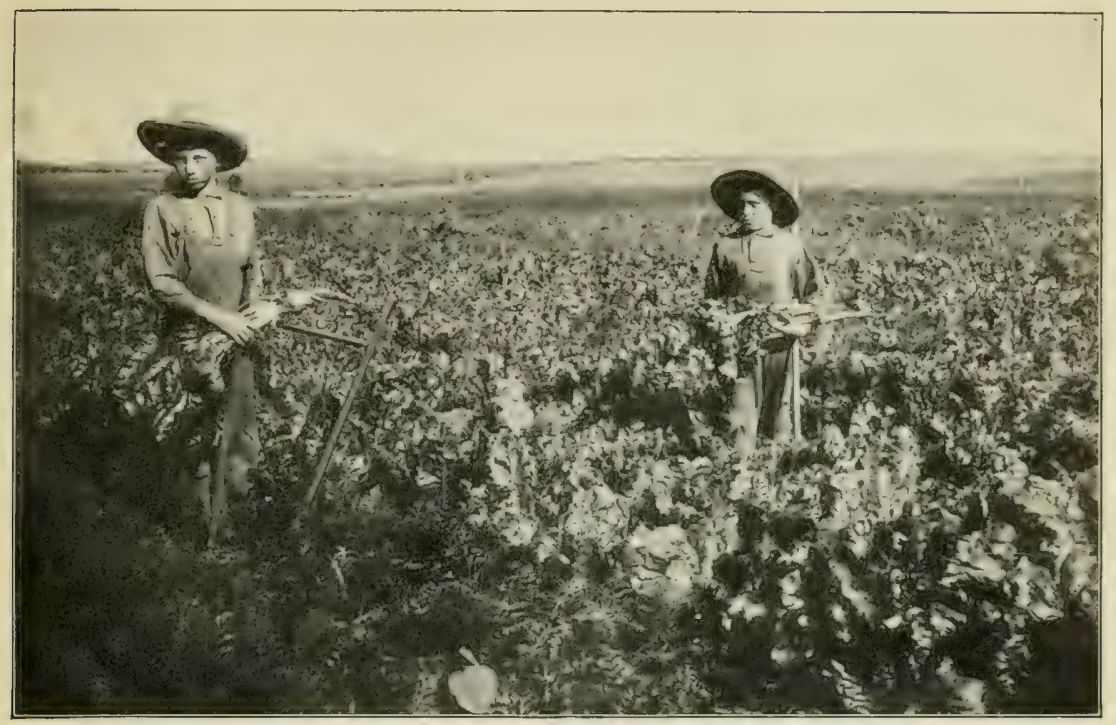

Fig. 1.-Winnebago County, Ill., Boys in their Field of Sugar Beets.

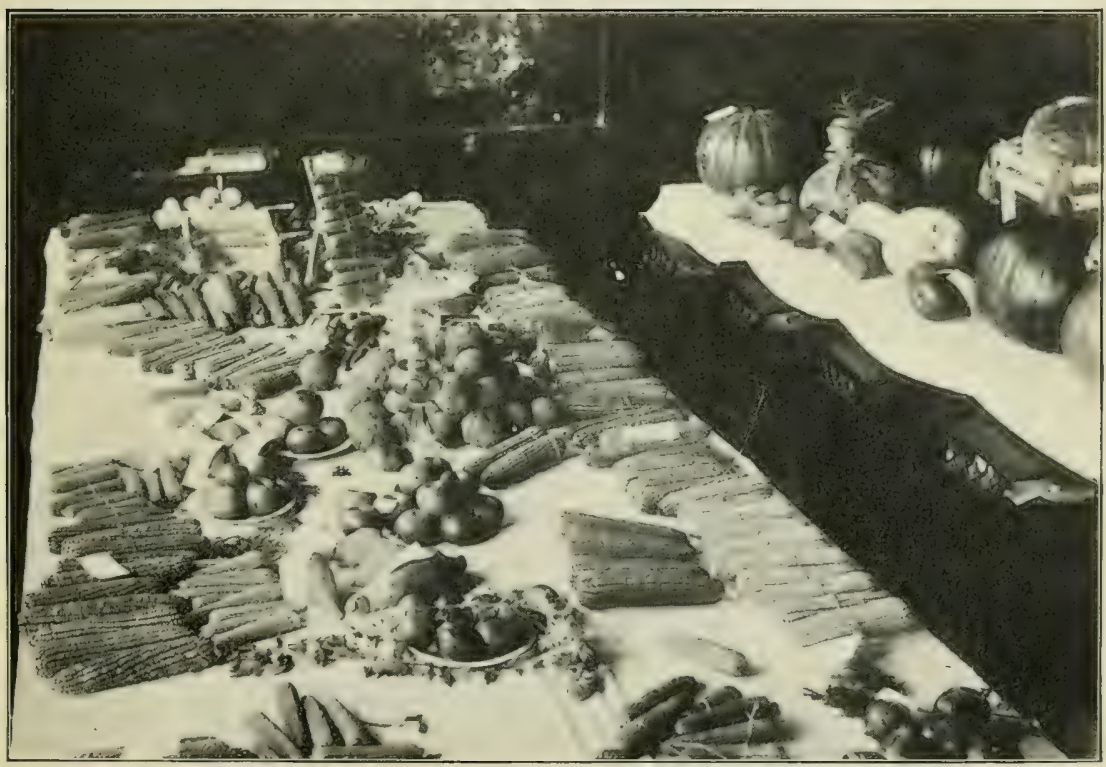

FIQ. 2.-RICHLAND TOWNSHIP SCHOOL FAIR IN KEOKUK COUNTY, IOWA. 

The school-fair movement has been self-supporting. By means of a small admission fee all expenses of the fairs and of securing music, judges, and speakers were paid and a balance of about $\$ 50$ was left in the club treasury. This is a matter of no little importance. A selfsupporting enterprise, if worthy, commands greater respect than one which depends upon charity or private subscription for its support. And without doubt this is a worthy enterprise. Aside from the good which has come to its members through their activity in organizing and directing a remarkable series of educational meetings, much has been accomplished toward arousing enthusiasm for better, more wholesome country life, and toward laying the foundation for a broader educational movement along agricultural lines.

Laying the foundation is about all that can be hoped for in this direction during the next few years. It was forty years after the corner-. stone of collegiate agricultural education in the United States was laid at the Michigan Agricultural College hefore the agricultural courses had been carried much above the basement line. But in the past four or five years the structure has gone up by leaps and bounds. The college courses have been developed and strengthened, the work of the experiment stations has been better systematized, and now greater attention is being given to extending the influence of these institutions beyond the bounds of the college campus. One of the direct results of this great forward movement in agricultural education, the aim of which is to extend agricultural education of some sort-formal or informal, advanced, intermediate, or elementary - to every grade of school attended by rural pupils, has been the organization of the boys' agricultural clubs. These clubs, though at present somewhat crude in their organization, are accomplishing much good, and are worthy of encouragement.

\section{SUMMARY.}

(1) Through their agricultural clubs the boys have been affected in many ways. Individually they have been led to observe more closely, to recognize good and bad qualities in the crops they have raised, and in the insects, fungi, and other things affecting these crops; they have met and learned to solvo some of the problems in the improvement of crops; they have learned that improvement in one direction is not always, or even usually, accompanied by improvement in all directions; they have learned the value of labor, the cost of producing crops, and how to keep simple accounts with different crops; they have been encouraged to read good literature, and have learned some of the sources of agricultural literature; their views have been broadened by contact with others and by visiting institutions of learning, highly developed farms, and other points of interest, and, finally, the power 
of taking the initiative has in many cases been strongly developed in them. As one of the direct results of the sugar-beet experiments, a few of the Illinois boys will raise sugar beets this year as a commercial venture. One sugar factory has already contracted with boys in Winnebago County to raise 20 acres of beets.

(2) Collectively the boys have learned the value of organized effort, of cooperation, and of compromise, and the social instinct has been developed in them - a matter of great importance in rural districts, where the isolated condition of the people has always been a great drawback to progress.

(3) The influence upon the communities at large, the parents as well as the children, has been wholesome. Beginning with an awakening of interest in one thing-better seed corn-the communities have rapidly extended their interest to other features of rural improvement, with the result that in the regions affected by the boys' agricultural club movement there has come about a general upward trend to the thoughts and activities of the people. 



\section{LIBRARY OF CONGRESS}

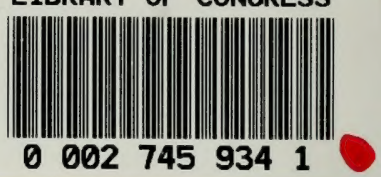

